\title{
Aspergillus fumigatus Antigen IgG Antibody Measurement
}

National Cancer Institute

\section{Source}

National Cancer Institute. Aspergillus fumigatus Antigen Ig G Antibody Measurement. NCI

Thesaurus. Code C130145.

A measurement of the Aspergillus fumigatus antigen Ig $G$ antibody in a biological specimen. 